\title{
PESTICIDE COMPATIBILITY OF BACTERIAL BIOLOGICAL CONTROL AGENTS WITH THE POTENTIAL TO CONTROL APHANOMYCES ROOT ROT IN PEAS
}

\author{
N. BOLSTRIDGE, E.E. JONES and A. STEWART \\ National Centre for Advanced Bio-Protection Technologies, PO Box 84, \\ Lincoln University, Canterbury, New Zealand \\ Corresponding author: bolstrin@lincoln.ac.nz
}

\begin{abstract}
Aphanomyces euteiches Drechsler can cause severe root rot in peas. Previous research has identified two bacterial isolates, Bacillus subtilis LU1241 and Paenibacillus polymyxa LU1133, able to suppress aphanomyces root rot of peas. If these bacteria are to be used as biological control agents in the field, it is important to know whether their efficacy is affected by commonly used pesticides. An assay was developed to determine the effect of selected fungicides, insecticides and herbicides on populations (colony forming units) of the two potential biological control agents. None of the fungicides (cyproconazole, metalaxyl-M, azoxystrobin and sulphur) inhibited growth of $P$. polymyxa and all stimulated growth of $B$. subtilis compared with the non-fungicide control. The herbicides sethoxydim and bentazone had no effect on either bacterium and diquat significantly inhibited growth of $B$. subtilis but had no effect on $P$. polymyxa. The insecticides pirimicarb, lambda-cyhalothrin and diazinon had no effect on $B$. subtilis. Pirimicarb had no effect on P. polymyxa, but abnormal colony morphology with spreading growth was observed for both diazinon and lambda-cyhalothrin. Different sensitivity to the pesticides was observed with each bacteria species and this could influence the use of the biological control agents in a field environment.
\end{abstract}

\section{OCCURRENCE AND DIVERSITY OF TRICHODERMA SPP. IN VEGETABLE CROPPING SYSTEMS}

\author{
E.L.T. BOURGUIGNON, K.L. McLEAN, E.E. JONES, \\ L.M. CONDRON and A. STEWART
National Centre for Advanced Bio-Protection Technologies, PO Box 84, Lincoln University, Canterbury, New Zealand \\ Corresponding author: bourguie@lincoln.ac.nz.
}

The ecology and diversity of indigenous Trichoderma species needs to be better understood in order to achieve natural suppression of soil-borne plant pathogens in the field. Bulk, rhizosphere and rhizoplane soil samples from onion and potato plots located at Pukekohe Research Station were collected. At the beginning of the season Trichoderma numbers in bulk soil were $1.9 \times 10^{3} \mathrm{cfu} / \mathrm{g}$ soil. In the rhizosphere and rhizoplane of onions numbers were $2.7 \times 10^{3}$ and $3.7 \times 10^{3} \mathrm{cfu} / \mathrm{g}$ soil respectively, and on potatoes, numbers were $3.1 \times 10^{3}$ and $5.4 \times 10^{3} \mathrm{cfu} / \mathrm{g}$ soil respectively. At the end of the growing season, Trichoderma colonies in rhizosphere soil were lower under both onion and potato $\left(9.1 \times 10^{2}\right.$ and $1.7 \times 10^{3} \mathrm{cfu} / \mathrm{g}$ soil) although this was not significant. In the rhizoplane soil, Trichoderma colonies were not recorded from onions but in potatoes the population was higher $\left(1.9 \times 10^{4} \mathrm{cfu} / \mathrm{g}\right.$ soil) but this was not significant. Trichoderma levels remained constant throughout the season in the bulk soil. Trichoderma isolates were identified to species level using ITS-RFLP. Trichoderma asperellum and T. harzianum were the most prevalent species for onion and potato in both the rhizosphere and rhizoplane soil. This population study will be continued over the next 2 years. 